\title{
PECULARITIES OF TRANSITION OF YOUNG PEOPLE WITH DISABILITIES TO ADULT LIFE
}

\author{
Rita Virbalienė \\ Mykolas Romeris university, Lithuania \\ Ingrida Baranauskienè \\ Klaipèda University, Lithuania
}

\begin{abstract}
During globalization process and development of technology the labor market is changing significantly and the demand for unskilled labor is decreasing. The integration of people with disabilities into society through such processes is even more complicated. The peculiarities of and risk factors and barriers to transition of young people with disabilities to adult life with specific attention to their career education and preparation for professional career presented by different researcher groups including Lithuanian examples are analyzed in the article. The critical review method and analysis of scientific literature are used.
\end{abstract}

Keywords: transition of young people to adulthood, career education, education of young people with disabilities.

\section{Introduction}

During globalization process and development of technology the labor market is changing significantly and the demand for unskilled labor is decreasing, as most people are replaced by robots, machines. The integration of people with disabilities into society through such processes is even more complicated. The main task of the school is to help pupils to know themselves, to find out their hobbies and disposal to one or another profession. At school students should find the activity appropriate to their needs and opportunities and develop their creative powers. Today it is especially important to teach a young person to solve their personal problems as well as problems of society independently and together with others, help them to acquire business and cultural literacy and knowledge and ability to live independently, prepare for further studies and activities.

One of the main tasks of basic education formulated in the concept of education in Lithuania is to consolidate and strengthen the motivation of students for the preparation for further studies and professional activities.

The main task of the school is to help the student to choose the most suitable educational path appropriate to his or her disposal, interests and abilities, and to make a reasoned opinion about the most appropriate for him or her further activities, i.e. career and career choices. 
Virbalienè \& Baranauskiene, 2018. Pecularities of Transition of Young People with Disabilities to Adult Life

It is very important to develop general skills at the school. General skills are universal competences that ensure success in various fields, enable a person to successfully learn, work, communicate and collaborate, think critically, solve problems independently, etc. It is the set of skills suitable for many areas of professional activity that is necessary for a modern person to be advanced. Man's abilities, their proper education and development are the keys for professional career success and satisfaction.

Preparation for the profession takes place during school time.Therefore, school and specifically teachers play a special role in helping to reconcile the student's aspirations and opportunities and adapting them to the socio-economic needs of a constantly changing society. Pupils at school need assistance for better understanding of themselves, find out what they like, what they want, and for which activity they have a vocation. Successful professional career is determined not only by professional skills, but also by the fact that a person has disorders (disabilities) because of which they often require mediation or escort services to get a job. It is also very important properly evaluate the readiness and suitability of each young person for one or another profession. Vocational skills are necessary for the proper realization of work activity tasks of concrete person and defined as the physical and mental qualities necessary for carrying out certain activities.

The problem analyzed in the article is very important for all young people, and especially for those with disorders (disabilities) who graduate the school and want to choose properly their professional careers.

The purpose of the article is to analyse peculiarities of and risk factors and barriers to transition of young people with disabilities to adult life with specific attention to their career education and preparation for professional career including development of general skills presented by different researcher groups.

\section{Theoretical framework and methods}

The existential, humanistic philosophy and philosophy of normalization are to be considered as the background of methodological research. According to existential philosophers (Mickūnas \& Stewart, 1974; Rudestam, 1982; Furman, 2001), each person is unique, valuable, and sees the world in his own way. In organization of a slightly mentally retarded young people career education process it is important to follow the idea of existential philosophy and actualize man "here and now". The only situation we can experience is present. Man can remember the past and plan the future. Therefore, the present situation is the only one that can be changed by career planning. Existentialism's pedagogical concept encourages educators and students interested in the issues of human existence, to overcome the satisfaction of life based on material well-being (Bitinas, 2000). 
From the existentialist point of view man (as a child) is free to choose, and educator's duty is to take into account the child's worldview and to teach consciously choose, to help learner to understand their options and to orientate towards them.

Humanistic philosophy is related to the respect for the human right to freedom, equality, the natural abilities and character development, personal unfolding. Its main principle is the recognition of value of each person's and respect for it. If a young man "wants to learn, develop, to know more and to do better everything, desires to create" (Rogers, 1973), than there will be successfully organized pre-vocational training, which is inseparable from the formulation of personality development objectives in the career curriculum. The school must at first help everyone to understand themselves, to understand their identity, to find purpose in life. Education should be oriented to the person, should help him to express himself and become better. All these goals can be achieved by satisfying the basic needs of the child: child has to be respected, loved, to feel safe psychologically, valued by others, adequately assess himself and plan and build the future.

The purpose of normalization is at any situation to provide an alternative for a person with a disability, which would be as much normal as possible, but not specific, special or unusual (Bakk \& Grunewald, 1997).

Methods. The method applied is critical review research method (Grant, 2009) and analysis scientific literature.

\section{Risk Factors and Barriers to the Transition of Young People}

It has been observed that in the scientific literature (Baltodano et al., 2005; Community Living Research Project, 2006; Wallerstein \& Duran, 2006). Learning Disabilities Association of Canada, 2007; Davis \& Vander Stoep, (2000), there are many data about strong correlation between physical, mental, behavioral, sensory, developmental and learning disorders (disability) and school failure and other negative consequences of the transition. The type of disability, according to many researchers (Caton \& Kagan, 2007; Van Naarden Braun, Yeargin-Allsopp \& Lollar, 2006; Wells, Sandefur, \& Hogan, 2003), affect the process and outcomes of the transition to adult life. Some articles (Community Living Research Project, 2006; Epp, M. A. (2006), Canadian National Institute for the Blind, 2006; Caton \& Kagan, 2007) emphasize the increased risk of adverse transitions, depending on the severity and type of disability. Other authors, however, warn that disability is just one of many complex factors of the process (Burchardt, 2004). These data indicate that the available evidence is not sufficient to conclude on the influence of disability type (Dowet et al., 2010). 
Virbaliene \& Baranauskiene, 2018. Pecularities of Transition of Young People with Disabilities to Adult Life

Aspirations of young people with disabilities are the same as those of healthy persons, but there are more obstacles to the transition to adult life. Often young people with disabilities have limited opportunities to participate in planning and evaluating services, especially in relation to education and career planning.

Many researchers from different countries have conducted research to reveal the most important and significant perspectives of young people, namely, the importance of participation in community life, of personal autonomy and of inclusion for the quality of life (Algozzine et al., 2001; Powers et al., 2007). Many works have been done to examine the populations of certain young people, the problems specific to certain groups associated with learning disorders (Cameron \& Murphy, 2002, Learning Disabilities Association of Canada, 2007, Salmon \& Kinnealey, 2007), health disorders (Anderson et al., 2004, 2006; Betz, 2004; Lotstein et al., 2005; Johnston, S. Cet et al., 2004; Ostlie et al., 2007; Saigal et al., 2006; Verlinde et al., 2004), development disorders (Betz \& Redcay 2002; Van Naarden Braun et al., 2006; Rapanaro et al., 2008), mental health and behavior problems (Armstrong et al., 2003; Carter \& Lunsford, 2005; Carter et al., 2006; Corbett et al., 2002; Feldman et al., 2004; Wagner \& Davis, 2006), Deaf and Blind Youth (Nagle, 2001). According to the literature review, although individual groups are characterized by separate problems, they all share similar challenges and their negative effects, such as unemployment and social exclusion (Committee on Disability in America, 2007; Murray, 2003; Stewart et al., 2001).

Young people with disabilities need certain skills to become mature, such as personal autonomy (self-attitude/self-determination), problem solvingand raising of goals (Connor, 2012, Madaus, 2005, Sitlington et al., 2010). The education of self-awareness gives young people the opportunity to assess individual strengths and challenges, albeit with collegiate aspirations. Development of skill to communicate his or her strengths and needs can be called personal autonomy (self-determination). E. M. Ankeny \& J. P. Lehmann (2011) states that independent (self-determined) individuals can have some control over their lives, since they can set future goals, linked to their reality, their situation knowing their strengths and needs. Personal self-determination (decision-making) skills enable young people with disabilities to play a more adult role (Ankeny \& Lehmann, 2010; Field, Sarver, \& Shaw, 2003). By strengthening independence, interdependence, facing problems and conflicts directly, young people develop greater self-esteem and confidence with greater responsibility. Personal autonomy can strengthen many young people who couldbecome adultseven during the transition period. In addition, the development of a gradual learning about their disability and how it affects learning is important for young people seeking vocational education (Connor, 2012). Sitlington et al. (2010) also mentioned the critical skills that young people need to develop: organization; prioritization, 
study habits, self-observation, self-defense, time management, relevant social, communication, reading and mathematical skills. The literature also highlights the need for young people with disabilities to have an understanding about the disciplines associated with vocational education and the need to apply them (Lan \& Lanthier, 2003, Sitlington et al., 2010).

Early schooling can be better organized through collaboration between school and vocational education and training institutions (Connor, 2012). In general, if more students with disabilities understand about:

a) themselves;

b) their disability (special education laws, their rights, procedures);

c) expectations for them,

Students will be better able to choose vocational education institutions later, and they will be better prepared for a successful transition to adult life. Skills include personal autonomy, self-defense, smart reading, science and math, problem solving, independence, communication, and more. All these skills can be fostered through early planning and dedicated teamwork.

Transition is part of a normal human development. Young people and adolescents with frequent disabilities experience greater stress and difficulties in post-secondary education (Carter, 2010; Field \& Hoffman, 1994, Sitlington, Nuebert, \& Clark, 2010).

They often experience problems with:

a) adequate support;

b) special education services;

c) changes in state policy;

d) time and behavior management;

e) performance skills;

f) personal autonomy.

All these problems later become a barrier to post-secondary education (Sitlington et al., 2010; Vander Stoep, Davis, \& Collins, 2000). Therefore, better results for young people can be obtained by examining the academic, social and psychological factors that affect the transition of young people with frequent disabilities from secondary to further vocational education (Bullock, 2013).

Given the perspective of context and interfaces, the performance and responsibility of all job roles remain crucial to the development of the feeling of being of inseparable part of corporations, i. e. the sense of embeddedness which is "a sense of belonging to a particular social network and being included in it" (Schultheiss, 2007). Work is understood as being culturally indivisible, related to life experience when people seek to create relationships, support, assurance, association and care (Blustein, 2011; Collin \& Young, 2000; Schultheiss, 2007). Deep interaction with family, partner, social networks and cultural factors affects all work-related solutions, transitions and experiences. 
Virbaliene \& Baranauskiene, 2018. Pecularities of Transition of Young People with Disabilities to Adult Life

According to Guichard's (2004, 2009) terminology, each of these interactions corresponds to various forms of subjective identity. By defining them, individuals become better informed about the more central or more peripheral role of each of these subjective forms of identity in their lives during a certain period of their lives. They also become aware about the interfaces that each subjective identity forms with each other in their system, especially if they are perceived as resources or barriers that are independent of each other. According to Guichard's (2004, 2009), also cultural, well-known interfacing allegations allow us to justify some of the findings of the overview, in particular the fact that today young people prefer not only personal contact for work (Biggart et al., 2002; Parada, 2007; Stokes \& Wyn, 2007), but also to balance work and non-work in their lives (Domene et al., 2012; Stokes \& Wyn, 2007; Wray-Lake et al., 2011), which was equated to professional success in Bujold and Fournier's (2008) study . The lives of people according to these authors or theories not only evolve according to the variety of peculiarities and paths, but also due to the active participation of individuals in their environment. Thus, it is possible to assume that the individual construct of their life reflects to a certain degree their experience and trajectories However, D. L. Blustein (2006, 2011) reiterated that not all individuals manage the "degree of choice of experience in their lives" (Blustein, 2011). Similarly, Schultheiss (2007) noticed that not everyone has opportunity to present themselves as "they would like", and in this process construct chosen careers. The ongoing changes in modern life have led to "significant changes in the landscape of the working world" (Blustein, 2011). Even highly educated workers all over the world experience diminishing career choices and thus challenge the traditional concept of a good working life career.

Nevertheless, according to Blustein (2011), such persons remain a minority. Many others, especially those in a disadvantaged situation and whose reality of life leaves room only for less-than-optimal education or career-related choices, becomes "working people, who have to survive" (Blustein, 2001).

The career of young people and their expectations of work and working activity are in line with many pre-requisites for choosing a career. Their understanding of career can be as an attribute of personal life (Stokes \& Wyn, 2007), the execution and enrichment of work (Bujold \& Fournier, 2008), the means of fulfilling expectations and happiness (Valore \& Viaro, 2007). However, these data exist along with others that are contradictory as the importance attached to material labor values (Wray-Lake et al., 2011), and consumption and socialization (Brooks, 2006). Maybe these data reveal the true regulation of the current working conditions and correspond to D. L. Blustein (2011) claims that this is the opposite to work, which many people around the world perform to survive. Today's world requires flexibility and adaptability. Personal life and 
career paths can be adapted successfully if persons are able to manage a changing situation, perceive what they like to work, acquire the competencies they need to perform the work and trust themselves (Perry \& Vanzandt, 1998).

There is a lack of vocational training and re-training services, and the disabled person who has acquired a profession has more opportunities to find work and become a full-fledged member of society. Currently, disabled people lack vocational rehabilitation services in Lithuania, training and retraining are organized in the areas not adapted to disabled people and therefore often available only to those with a mild disability (What should be known about the integration of people with disabilities, 2010).

Studies carried out in Lithuania show that vocational training for disabled people gives positive results: people with disabilities become more confident, their psychological status improves, they become aware that disability is not the main barrier to employment, they expand the circle of friends, the knowledge gained encourages further personal development, acquired qualification provides a greater sense of social security, they take a more courageous look at the future, and so on. (Moskvina, Okunevičiūtè-Neverauskienè, 2011)

\section{Conclusions}

Often young people with disabilities experience more obstacles in their transition to adulthood and have limited opportunities to participate in planning and evaluating services, especially in relation to education and career planning.

Independent (self-determined) individuals can have some control over their lives, since they can set future goals, linked to their reality, their situation knowing their strengths and needs. Personal autonomy (self-determination) skills enable young people with disabilities to play a more adult role. Personal autonomy can strengthen many young people who couldbecome adults even during the transition period.

Preparation for the profession takes place during school time. Therefore, school and specifically teachers play a special role in helping to reconcile the student's aspirations and opportunities and adapting them to the socio-economic needs of a constantly changing society. Pupils at school especially those with disabilities need assistance for better understanding of themselves, find out what they like, what they want, and for which activity they have a vocation.

Studies carried out in Lithuania show that vocational training for disabled people gives positive results. However, it is also very important to develop general skills at the school. General skills are universal competences that ensure success in various fields, enable a person including those with disabilities to successfully learn, work, communicate and collaborate, think critically, solve problems independently, etc. It is the set of skills suitable for many areas of professional 
Virbaliene \& Baranauskiene, 2018. Pecularities of Transition of Young People with Disabilities to Adult Life

activity that is necessary for a modern person to be advanced. Man's abilities, their proper education and development are the keys for professional career success and satisfaction.

\section{References}

Algozzine, B., Browder, D., Karvonen, M., Test, D. W., \& Wood, W. M. (2001). Effects of interventions to promote self-determination for individuals with disabilities. Review of Educational Research, 71 (2).

Ankey, E. M., \& Lemann, J. P. (2010). He transition lynchpin: The voices of individuals with disabilities who attended a community college transition program. Comunity College Journal of Research and Practice 34.

Ankey, E. M., \& Lemann, J. P. (2011). Journey towards selfdetermination: Voices of students with disabilities who participated ina secondary transition program on a community college campus. Remedial and Special Education, 32 (4).

Andersen, B. B., Vogel, A., Mortensen, E. L., Hasselbalch, S. G., \& Waldemar, G. (2006). Patient versus informant reported quality of life in the earliest phases of Alzheimer's disease. International journal of geriatric psychiatry, 21 (12).

Bakk, A., \& Grunewald, K. (1997). Globa. Vilnius: Avicena.

Bitinas, B. (2000). Philosophy of education. Vilnius: Enciklopedija.

Braun, K. V. N., Yeargin-Allsopp, M., \& Lollar, D. (2006). Factors associated with leisure activity among young adults with developmental disabilities. Research in developmental disabilities, 27 (5), 567-583.

Betz, C. L., \& Redcay, G. (2002). Lessons learned from providing transition services to adolescents with special health care needs. Issues in Comprehensive Pediatric Nursing, 25 (2), 129-149.

Betz, C. L. (2004). Transition of adolescents with special health care needs: review and analysis of the literature. Issues in comprehensive pediatric nursing, 27 (3), 179-241.

Blustein, D. L. (2011). A relational theory of working. Journal of Vocational Behavior, 79 (1), 1-17.

Blustein, D. L. (2001). Extending the reach of vocational psychology: Toward an inclusive and integrative psychology of working. Journal of Vocational Behavior, 59 (2), 171-182.

Brooks, T. M., Mittermeier, R. A., da Fonseca, G. A., Gerlach, J., Hoffmann, M., Lamoreux, J. F., \& Rodrigues, A. S. (2006). Global biodiversity conservation priorities. Science, 313 (5783), 58-61.

Burchardt, T. (2004). Capabilities and disability: the capabilities framework and the social model of disability. Disability \& society, 19 (7), 735-751.

Bujold, C., \& Fournier, G. (2008). Occupational representations of workers in nonstandard and precarious work situations. Journal of Career Assessment, 16 (3), 339-359.

Cameron, L., \& Murphy, J. (2002). Enabling young people with a learning disability to make choices at a time of transition. British Journal of Learning Disabilities, 30 (3), 105-112.

Carter, E. W., \& Lunsford, L. B. (2005). Meaningful work: Improving employment outcomes for transition-age youth with emotional and behavioral disorders. Preventing School Failure: Alternative Education for Children and Youth, 49 (2), 63-69.

Caton, S., \& Kagan, C. (2007). Comparing transition expectations of young people with moderate learning disabilities with other vulnerable youth and with their non-disabled counterparts. Disability \& society, 22 (5), 473-488. 
Coetzer, A., \& Sitlington, H. (2014). What knowledge, skills and attitudes should strategic HRM students acquire? A Delphi study. Asia Pacific Journal of Human Resources, 52 (2), 155-172.

Collin, A., \& Young, R. A. (Eds.). (2000). The future of career. Cambridge University Press.

Connor, J. (2012). Helping students with disabilities transition to college. 21 tips for students with LD and/or ADD/ADHD. TEACHING Exceptional chirdren, Vol. 44, No. 5. Copyright CEC. 17-25.

Davidson, J. E., Powers, K., Hedayat, K. M., Tieszen, M., Kon, A. A., Shepard, E., \& Ghandi, R. (2007). Clinical practice guidelines for support of the family in the patient-centered intensive care unit: American College of Critical Care Medicine Task Force 2004-2005. Critical care medicine, 35 (2), 605-622.

Davis, M., \& Vander Stoep, A. (2000). The transition to adulthood among adolescents who have serious emotional disturbance. DIANE Publishing.

Dow, W. H., Schoeni, R. F., Adler, N. E., \& Stewart, J. (2010). Evaluating the evidence base: Policies and interventions to address socioeconomic status gradients in healtha. Annals of the New York Academy of Sciences, 1186 (1), 240-251.

Epp, M. A. (2006). Closing the 95 percent gap: Library resource sharing for people with print disabilities. Library Trends, 54 (3), 411-429.

Feldman, R., \& Eidelman, A. I. (2004). Parent-infant synchrony and the social-emotional development of triplets. Developmental psychology, 40 (6), 1133.

Geurts, H. M., Corbett, B., \& Solomon, M. (2009). The paradox of cognitive flexibility in autism. Trends in cognitive sciences, 13 (2), 74-82.

Grant, M. J., \& Booth, A. (2009) A typology of reviews: an analysis of 14 review types and associated methodologies. Health Information and Libraries Journal, 26, 91-108.

Lan, W., \& Lanthier, R. (2003). Changes in students' academic performance and perceptions of school and self before dropping out of schools. Journal of Education for Students Placed at Risk, 8 (3), 309-332.

Lane, K. L., Carter, E. W., Pierson, M. R., \& Glaeser, B. C. (2006). Academic, social, and behavioral characteristics of high school students with emotional disturbances or learning disabilities. Journal of emotional and behavioral disorders, 14 (2), 108-117

Law, M., Cooper, B., Strong, S., Stewart, D., Rigby, P., \& Letts, L. (1996). The personenvironment-occupation model: A transactive approach to occupational performance. Canadian journal of occupational therapy, 63 (1), 9-23.

Liu, C. H., \& Matthews, R. (2005). Vygotsky's Philosophy: Constructivism and Its Criticisms Examined. International Education Journal, 6 (3), 386-399.

Lotstein, D. S., McPherson, M., Strickland, B., \& Newacheck, P. W. (2005). Transition planning for youth with special health care needs: results from the National Survey of Children with Special Health Care Needs. Pediatrics, 115 (6), 1562-1568.

Madaus, J. W. (2005). Helping students with learning disabilities navigate the college transition maze. Teaching Exceptional Children, 37 (3), 32-37.

Mickūnas, A., \& Stewarts, D. (1990). Exploring Phenomenology: A guide to the field and its literature. 1974. American Library Association leidyklos. Ohio University Press.

Murray, J. (2007). The cycle of punishment: Social exclusion of prisoners and their children. Criminology \& Criminal Justice, 7 (1), 55-81.

Nagle, K. (2001). Transition to employment and community life for youths with visual impairments: Current status and future directions. Journal of Visual Impairment \& Blindness (JVIB), 95 (12). 
Virbaliene \& Baranauskiene, 2018. Pecularities of Transition of Young People with Disabilities to Adult Life

Okunevičiūtè-Neverauskienė L., \& Moskvina, J. (2011). Aktyvi darbo rinkos politika: teorija ir praktika: monografija. Vilnius: Technika,. $256 \mathrm{p}$.

Okunevičiūtè-Neverauskienė, L., \& Moskvina, J. (2008). Socialiai pažeidžiamo jaunimo problemos integracijos į darbo rinką kontekste. Filosofija. Sociologija, 19 (2): 41-51.

Östlie, I. L., Dale, Ö., \& Möller, A. (2007). From childhood to adult life with juvenile idiopathic arthritis (JIA): a pilot study. Disability and rehabilitation, 29 (6), 445-452.

Perry, N., \& Vanzandt, Z. (1998). Mano pasirinkimogalimybès. Atviros Lietuvos fondas. Kaunas: Aušra.

Perry, N., \& Vanzandt, Z. (1998). Žvilgsnis ị ateitị. Atviros Lietuvos fondas. Kaunas: Aušra.

Rapanaro, C., Bartu, A., \& Lee, A. H. (2008). Perceived benefits and negative impact of challenges encountered in caring for young adults with intellectual disabilities in the transition to adulthood. Journal of Applied Research in Intellectual Disabilities, 21 (1), 34-47.

Rogers, D. P. (1973). A Systens analysis of correlates of network openness in organition communication. Unpublished Doctoral Disertation, Ohio University.

Rudestam, K. E. (1982). Experiential groups in theory and practice. Monterey, CA: Brooks/Cole.

Saigal, S., Stoskopf, B., Pinelli, J., Streiner, D., Hoult, L., Paneth, N., \& Goddeeris, J. (2006). Self-perceived health-related quality of life of former extremely low birth weight infants at young adulthood. Pediatrics, 118 (3), 1140-1148.

Salmon, N., \& Kinnealey, M. (2007). Paving Rough Roads: Transition to life beyond the classroom as experienced by students with disabilities and their families. Exceptionality Education Canada, 17.

Schultheiss, D. E. P. (2007). The emergence of a relational cultural paradigm for vocational psychology. International Journal for Educational and Vocational Guidance, 7 (3).

Stokes, H., \& Wyn, J. (2007). Constructing identities and making careers: Young people's perspectives on work and learning. International Journal of Lifelong Education, 26 (5), 495-511.

Stewart, J. M. (2001). The impact of health status on the duration of unemployment spells and the implications for studies of the impact of unemployment on health status. Journal of health economics, 20 (5).

Stokes, H., \& Wyn, J. (2007). Constructing identities and making careers: Young people's perspectives on work and learning. International Journal of Lifelong Education, 26 (5).

Essex, M. J., Kraemer, H. C., Armstrong, J. M., Boyce, W. T., Goldsmith, H. H., Klein, M. H., \& Kupfer, D. J. (2006). Exploring risk factors for the emergence of children's mental health problems. Archives of general psychiatry, 63 (11), 1246-1256.

Verlinde, F., Massa, G., Lagrou, K., Froidecoeur, C., Bourguignon, J. P., Craen, M., \& Maes, M. (2004). Health and psychosocial status of patients with Turner syndrome after transition to adulthood: the Belgian experience. Hormone Research in Paediatrics, 62 (4), 161-167.

Vanier, J. (1998). Bendruomenė atleisti ir švęsti. Vilnius: Vyturys.

Wray-Lake, L., \& Syvertsen, A. K. (2011). The developmental roots of social responsibility in childhood and adolescence. New directions for child and adolescent development, 2011 (134), 11-25.

Wallerstein, N. B., \& Duran, B. (2006). Using community-based participatory research to address health disparities. Health promotion practice, 7 (3), 312-323. 
Wagner, M., \& Davis, M. (2006). How are we preparing students with emotional disturbances for the transition to young adulthood? Findings from the National Longitudinal Transition Study-2. Journal of Emotional and Behavioral Disorders, 14 (2), 86-98.

Wells, T., Hogan, D. P., \& Sandefur, G. D. (2003). What happens after the high school years among young persons with disabilities?. Social Forces, 82 (2), 803-832.

\section{ELECTRONIC}

Putting a Canadian Face on Learning Disabilities (2007). provides a foundation for future studies in Canadian data surveys. www.pacfold.cahttp://www.statcan.ca/Daily/English/ 071203/d071203a.htm

What should be known about the integration of people with disabilities/ http://karjeroscentras.eu/wp-content/uploads/2015/04/Ka-verta-zinoti-apie-neigaliujuintegracija_FIN.pdf 